Haiyan Yin,

Henan Institute of Science and Technology, China

ORCID ID, 0000-0001-7439-1655

email: yinhaiyan1126@126.com

Zhiping Huo,

Henan Institute of Science and Technology, China

ORCID ID, 0000-0002-2077-2660

email: 15993051993@126.com

Nataliia Klietsova,

Ph.D., Sumy National Agrarian University, Ukraine

ORCID ID, 0000-0003-4910-8912

email: klietsovanataliia@gmail.com

Zongkeng Li,

Hezhou University, China

ORCID ID, 0000-0002-4727-2391

email: 463952482@qq.com

Yongsheng Zhang,

Henan Institute of Science and Technology, China

ORCID ID, 0000-0001-9322-7172

email:270460660@qq.com

Correspondence author: klietsovanataliia@gmail.com

\title{
INNOVATIONS IN HUMAN RESOURCE MANAGEMENT: WILLINGNESS AND ABILITY OF LONG- TERM CARE INSURANCE
}

Abstract. This paper summarizes the arguments within the scientific discussion on the investigation of human resource management of willingness and ability of long-term care insurance. The main purpose of the research is to investigate human resource management of willingness and ability of long-term care insurance considering the innovative international experience and the case of Henan province in China. Systematization literary sources and approaches for solving how the person could be motivated to use long-term care insurance indicate that this goal could be reached by issuing questionnaires. The relevance of the decision of this scientific problem is that the demand for long-term care insurance, domestic and foreign scholars mainly use questionnaire survey to conduct quantitative and qualitative research. Investigation of the proposed topic in the paper is carried out in the following logical sequence: the method of expert analysis allowed forming the survey of long-term care insurance. The research's theoretical and methodological basics are general scientific and special methods of certain economic phenomena and processes' cognition. The dialectical method was used to synthesize theoretical and methodological foundations of human resource management of willingness and ability of long-term care insurance foreign countries and China and formulate conclusions. Methodological tools of the research methods were respondents from January 20, 2020, until the end of March 31, 2020. The paper presents the results of the empirical analysis that the proportion of those willing to participate in the long-term care insurance system with an income of "less than 2,000 yuan» is $65.4 \%$; the proportion of those willing to participate in the long-term care insurance system with an income of «2000-4000 yuan» is 69.0\%, and the proportion of those willing to participate in the long-term care insurance system with an income of «4000-6000 yuan» is $74.1 \%$. The regression analysis as the statistical method was used to determine whether and to what extent dependent and independent variables are significant. The research empirically confirms and theoretically proves that the factors of the insurance awareness model and the regression of Q24 «are you willing to participate in the longterm care insurance system» are not significant, indicating that the insurance awareness factor is not an influential

Cite as: Yin, H., Huo, Zh., Klietsova, N., Li, Z., \& Zhang, Y. (2021). Innovations in Human Resource Management: Willingness and Ability of Long-Term Care Insurance. Marketing and Management of Innovations, 1, 261. 277. http://doi.org/10.21272/mmi.2021.2-22 

Long-Term Care Insurance

factor for the old-age care insurance demand. Therefore, the original hypothesis was denied, and the insurance consciousness model factors became not significantly related to the willingness of demand for long-term care insurance. The research results could be useful for those who have a deal with responsible staff, but for this reason, some indicators could influence his behavior. Summing up the results of the held scientific research it could be done the following recommendations. First of all, strengthening publicity and standardize management of long-term care insurance system. Secondly, that should be accelerated the development of the nursing industry with aging, chronic diseases, and other increasingly serious, China's medical resources are very scarce, especially in the nursing industry. Thirdly, it would be progressive if China absorbed the foreign long-term care insurance experience. Fourthly, it should be improved the design of long-term care insurance and increased the types of insurance products.

Keywords: care insurance, China, expert evaluation, human resource management, innovation, international experience, long-term insurance.

Introduction. The aging of the population is a common phenomenon in all countries or regions in the world. According to the data from the seventh census in 2020, people aged 60 and over accounted for 18.70 percent of China's total population, up to 5.44 percent from the figure from the sixth census in 2010 . In 2010 , the population aged 65 and above accounted for $8.87 \%$ of the national population in the sixth census, which increased by $1.91 \%$ compared with the data of the fifth census in 2000 (Yang et al., 2017). However, according to the seventh census in 2020, the number of people aged 65 and above in China is 19064 million, accounting for $13.50 \%$. When the proportion exceeds $14 \%$, it marks the arrival of a «deeply aging society». Therefore, China is likely to enter a «deeply aging society» in the next 5-10 years. At present, the elderly population in China is characterized by a large number, rapid growth, and a gradual aging trend. In the 1970s, China implemented the family planning policy, which led to a shrinking family structure. In addition, the emergence of empty-nest families makes it difficult for family members to provide timely and adequate care when people have long-term care needs, and the elderly cannot meet the care needs. Long-term care insurance could provide professional medical care and basic daily care, ensuring that family members' daily work is not affected.

As the elderly population grows, so does the number of disabled and semi-disabled elderly people. Coupled with the inability of family members to provide timely and adequate care, the demand for longterm care insurance is also increasing. It is found that the long-term care insurance system is beneficial to protect the rights and interests of the disabled or mentally ill elderly. Besides, it promotes the development of social insurance in China. Therefore, every country in the world has to carry out a long-term care insurance pilot in some areas. However, for this reason, the HR management that motivates people to have insurance should be an inseparable part of this process. That's why the topic of this article is actual. This paper aims to investigate human resource management of willingness and ability of long-term care insurance, taking into account the innovative international experience and the case of Henan province in China. That could be reached by issuing questionnaires and then uses SPSS to summarize and analyze people's specific needs and ability to participate in long-term care insurance. Finally, it puts forward some suggestions to promote the development of the long-term care insurance system from different perspectives.

Literature Review. Analyzing current circumstances even in the conditions of COVID-19, such scientists as Klymchuk and Mikhailov made the accent that the essential precondition for the development of society should be the research that «paying special attention to personnel, that creates conditions for economic growth and competitiveness in conditions of maximum use of innovations» (Klymchuk and Mikhailov, 2018; Huo et al., 2019). This study considers these aspects to be the anvil upon which the management process of human resources is created. That's why before holding research concerning the willingness and ability of long-term care insurance in Chine, the innovative international experience «determining what concepts such as motivation and stimulation of personnel may be used» was 

Long-Term Care Insurance

researched for this case study. It was done in different fields, such as staff management in banking activity (Kurylo et al., 2021), in the sphere of staff recruitment for vacant positions with the application of social networks (Klietsova and Mykhailova, 2021), when the process of digitalization is extending very quickly and the question how to involve the human beings for the long-term care insurance was raised. It was done the preliminary investigation (Klietsova and Zhang, 2020; Szostek, 2021; Kuznichenko et al., 2021) as to the optimization of the labor rights' violation during the pandemic «2019-nCoV», and it was also concluded that the willingness and ability of long-term care insurance could be one of the tools that help to overcome the unpredictable circumstance; as well as was researched the impact of demographic characteristics on counterproductive work behaviors.

At the same time, it was done deep research concerning long-term care insurance in Chine and other foreign countries. Thus, it was determined that such scientists and scientists-practitioners as (Xiangyou and Xueping, 2006; Shi, 2008; Zhang, 2009; Li and Wang, 2010) and others have mentioned, due to China's aging population boom is coming, aged care costs rising, family size structure increasingly narrowed, and inadequate social, medical security, makes it necessary to establish the elderly care insurance. For these reasons, other foreign scientists propose some approaches for the Ukrainians to do this service to be available for everyone and cheap. Thus, it was revealed that for the insurance company, the main pluses in the running of virtual business could be: lower costs concerning the organization of the company's website; fewer costs concerning the transactions for customer service operations; "expansion of geographical diversification of company insurance products; an opportunity to increase the sale of insurance products at the expense of open access to customers from around the world; customer service on a qualitatively new level - seven days a week, 365 days a year» (Yanyshyn et al., 2019). There was also paid great attention for the research that showed the presence of healthcare in special households' groups, the way of accelerating the transformation of the management process with human resources, as well as the adequate assessment of the countries' investment potential in the content of health insurance was also deeply investigated (Antosova et al., 2019; Kasaeva, 2019). Zhang (2011) underlines that the favorable factors for the development of old-age care insurance include the aging population trend, the rising nursing costs, the high burden of the elderly, the high medical costs, and the lack of medical securityю Moreover, He and Li (2014) assessed the payment capacity of farmers; Sheng et al. (2020) studied the pilot system and current situation of long-term care insurance and put forward corresponding suggestions in Suzhou. Analysis of these authors' publications showed reviled that that old-age care insurance is very necessary. When insured persons need nursing services due to illness or the ability, that could pay part of his or her expenses, thus easing the economic burden of individuals and families. In their scientific works, Brown and Finkelstein (2007) used HRS data to make an empirical analysis on the pricing and returns of the long-term care insurance market and studied the reasons why the market was too small from the supply side of long-term care insurance. Brown et al. (2012) designed questionnaires to study more specific reasons why people have less demand for long-term care insurance. So, it was determined, first of all, it's because of the personal preference and self-assessment disability probability. Secondly, there always exist the alternatives to insurance, such as savings deposits that cover the cost of long-term care. Thirdly, the existing alternatives to long-term care. And finally, long-term care costs are high. Szczepanski (2018) paid great attention to research regarding the usage of special economic schemes under the reformation of the professional pension schemes in Great Britain (it means automatic enrollment but with the opportunity to refuse them in a definite period). Yashkina (2016) identified the risks in health insurance pricing using a regression model of demand on price dependence. Volosovych et al. (2021) defined that the pandemic COVID-19 has influenced different economic sectors, and insurance was not the exception, which has become a vivid problem that accelerated the innovations. This pandemic has shown the ineffectiveness of the usual interactive models between the insurers and their clients. These times were concentrated only on insurance companies' attempts to provide new investments and 
innovations in the digital future. That's why even now, it's actual to have long-term care insurance. But Melnyk et al. (2021) made the accent on the method of unprofitable enterprises analysis that the Ministry for Development of Economy, Trade and Agriculture of Ukraine uses to reveal the stage of the shadow economy, taking into account the kind of economic activity, the level of «shadowing of the insurance services sector in Ukraine and its regions in 2013 and 2018».

We have to admit that claim costs' variability demonstrates the key risk component, which should be calculated beforehand while implementing the internal schemes assessing the insurance company's solvency. It was researched by D'Ortona and Melisi (2017). It was defined that this component could make the base for the difference between future claims' payments and the provisions set for these claims.

$\mathrm{Li}$ and Prince (2016) studied the reasons for residents' different reactions to the long-term care insurance system from three aspects: inheritance incentive, financial literacy, and insurance understanding level. Such Chinese scientists as Yin et al. (2019) underline that the United States was one of the early countries to establish a long-term care insurance system. The American Health Insurance Institute gave a clear definition of long-term care. In a longer period, for the continuous suffering from chronic diseases, such as Alzheimer's disease and other cognitive impairment or disability, that is, the care provided by the person with functional impairment. It includes medical services, social services, home services, delivery services, or other supportive services. Moreover, analyzing their research from the point of HR-Management substantially, the elderly long-term care guarantee should include the elderly inhabitants and create a long-term care system for this layer of the population. Based on the review of domestic research results, these scientists draw on the experience of the USA, Japan, Germany as to the long-term care commercial insurance the implementations of the definite proposals concerning the choice of long-term care insurance in China. At the same time, special provisions of the economic theory of «path dependence» were put into the methodological basis of the research concerning the transformation of the socio-economic system's state, which is conditioned by the introduction of a new rule in implementing the reforms (Mykhailova et al., 2018; Zaks, 2013). It could become the analogical base for human understanding the necessity of long-term insurance starting from the person's birth. But there could be another way of developing the human capital's management. Thus, under these conditions, the effect of hysteresis may arise. It means that the new rules could fall into the institutional trap and stay in it even when perturbations often disappeared.

The literature review found that the research on long-term care insurance, the introduction of foreign systems, and the macro construction of domestic systems were rich. However, the domestic system construction only stays at the macroscopic level. The concrete countermeasure and the standard implementation research are insufficient. Domestic scholars mainly use questionnaire surveys to conduct quantitative and qualitative research regarding the demand for long-term care insurance. The questionnaire is mainly set on individual characteristics and economic conditions, while several studies on physical condition and subjective cognition. China's old-age care insurance demand market has great potential and has attracted increasing attention from domestic scholars. The author underlined that the analysis of old-age care insurance demand in China should not be limited to a certain place or several surveys. The representative is not strong. Moreover, domestic scholars are still unscientific in calculating the demand cost of old-age care insurance, which is mainly estimated through the charging standards of several nursing homes. Therefore, the experience of the elderly care insurance system in developed countries was explored. In most developed countries long - term care insurance has been more mature insurance. Most studies on long-term care insurance by foreign scholars adopt quantitative analysis to study the relationship between long-term care insurance and other related factors from different perspectives to put forward relevant countermeasures. It enriches the quantitative analysis methods of long-term care insurance and provides some references for the research of long-term care insurance in China. 
Methodology and research methods. The research's theoretical and methodological basics are general scientific and special methods of certain economic phenomena and processes' cognition. The dialectical method was used to synthesize theoretical and methodological foundations of human resource management of willingness and ability of long-term care insurance foreign countries and China and formulate conclusions. This study involved the abstract and logical investigation methods of the economic process in long-term care insurance. Moreover, the method of expert analysis allowed forming the survey of long-term care insurance. The study was based on such blocks.

The survey of long-term care insurance. The title of the questionnaire is the survey of demand willingness and ability to participate in long-term care insurance, which mainly includes the following six aspects: the first is the personal characteristics of the respondents, the second is their family status, economic status, and health status, third, the cognitive status and insurance awareness of the respondents.

Issue and collect questionnaires.

1) The issuance of questionnaires. The survey would start on January 20, 2020, and end on March 31, 2020. Questionnaires were distributed in the field and on the Internet. A total of 218 questionnaires were distributed.

2) Collection of questionnaires. Table 1 shows the results of this survey.

Table 1. City frequency analysis

\begin{tabular}{lll}
\hline City & Frequency & The percentage (\%) \\
\hline Zhengzhou & 46 & 21.1 \\
Kaifeng & 28 & 12.8 \\
Xinxiang & 33 & 15.1 \\
Shangqiu & 28 & 12.8 \\
Xinyang & 20 & 9.2 \\
Zhumadian & 18 & 8.3 \\
Xuchang & 25 & 11.5 \\
Nanyang & 20 & 9.2 \\
Total & 218 & 100 \\
\hline
\end{tabular}

Sources: developed by the authors.

As it could be seen, a total of 218 questionnaires were collected, of which one was incomplete and one was wrong. Therefore, 216 valid questionnaires were collected, with an effective rate of $99.1 \%$.

3) Sample characteristics. It was analyzed registered residence.

Table 2. Sample characteristics of registered permanent residence

\begin{tabular}{lll}
\hline Registered residence & Frequency & The percentage (\%) \\
\hline Urban & 97 & 44.9 \\
Rural & 119 & 55.1 \\
Total & 216 & 100.0 \\
\hline
\end{tabular}

Sources: developed by the authors.

Table 2 indicated that among 216 valid questionnaires, 97 respondents came from urban accounting for $44.9 \%$ of the total number of respondents; 119 respondents came from rural, accounting for $55.1 \%$ of the total number of respondents.

Gender distribution. 
H., Yin, Zh., Huo, N., Klietsova, Z., Li, Y., Zhang. Innovations in Human Resource Management: Willingness and Ability of Long-Term Care Insurance

Table 3. Gender sample characteristics

\begin{tabular}{lll}
\hline Gender & Frequency & The percentage (\%) \\
\hline Male & 77 & 35.6 \\
Female & 139 & 64.4 \\
Total & 216 & 100.0 \\
\hline
\end{tabular}

Sources: developed by the authors.

Through the frequency analysis of gender, it is found that among 216 respondents, there are 77 male respondents, accounting for $35.6 \%$ of the total number; there are 139 female respondents, accounting for $64.4 \%$ of the total number.

Age distribution.

Table 4. Age sample characteristics

\begin{tabular}{lll}
\hline Age & Frequency & The percentage (\%) \\
\hline $18-30$ & 179 & 82.9 \\
$31-40$ & 11 & 5.1 \\
$41-50$ & 14 & 6.5 \\
$51-60$ & 9 & 4.2 \\
Above 61 & 3 & 1.4 \\
Total & 216 & 100.0 \\
\hline
\end{tabular}

Sources: developed by the authors.

Through the frequency analysis of age, it could be found that the frequency of respondents aged 18 30 is the highest, accounting for $82.9 \%$. Although other age groups also appear, the frequency is relatively low.

4) Basic information of demand willingness. It was necessary to research the willingness of people to participate in long-term care insurance. It was necessary to predict how to motivate the person.

Table 5. Willingness to participate in long-term care insurance

\begin{tabular}{ccc}
\hline Are you willing to participate in long-term care insurance & Frequency & The percentage (\%) \\
\hline No & 74 & 34.3 \\
Yes & 142 & 65.7 \\
Total & 216 & 100.0 \\
\hline
\end{tabular}

Sources: developed by the authors.

Thus, 65.7 percent of respondents are willing to participate in long-term care insurance, while 34.3 percent are unwilling to participate in long-term care insurance. In general, the demand willingness for long-term care insurance is relatively large.

Content.

Table 6. The form of long term care service you would most like to choose

\begin{tabular}{lll}
\hline The form & Frequency & The percentage (\%) \\
\hline Community home care & 133 & 61.6 \\
Institutional care & 45 & 20.8 \\
Inpatient medical care & 23 & 10.6 \\
Others & 15 & 6.9 \\
Total & 216 & 100.0 \\
\hline
\end{tabular}

Sources: developed by the authors. 
H., Yin, Zh., Huo, N., Klietsova, Z., Li, Y., Zhang. Innovations in Human Resource Management: Willingness and Ability of Long-Term Care Insurance

Table 6 demonstrates that $61.6 \%$ of the respondents hope to choose the service form of community home care, and $20.83 \%$ want to choose nursing home care. Fewer respondents chose the form of inpatient medical care and other forms. The next step was to choose the type of long-term care insurance benefits (Table 7).

Table 7. The type of long-term care insurance benefits

\begin{tabular}{lll}
\hline The type & Frequency & The percentage (\%) \\
\hline Kind & 21 & 9.7 \\
Cash & 103 & 47.7 \\
Service & 85 & 39.4 \\
Others & 7 & 3.3 \\
Total & 216 & 100.0 \\
\hline
\end{tabular}

Sources: developed by the authors on their own research (2020).

Table 7 shows that $47.7 \%$ of respondents tend to choose the way of cash payment. $39.4 \%$ of the respondents tend to choose professional service payment. There are fewer choices of payment in kind and other ways.

5) Analysis of factors affecting willingness.

The theoretical basis of the analysis of factors affecting demand willingness is the optimal insurance theory. The selected variables also refer to the six variables affecting the insurance demand mentioned in the optimal insurance theory to some extent. In the process of analysis, cross contingency table and regression analysis are mainly used.

Cross analysis. Registered permanent residence.

Table 8. Crosstable between account location and willingness to participate in long term care insurance

\begin{tabular}{|c|c|c|c|c|}
\hline Variable & & tistical indicators & Are you w & -term care insurance \\
\hline $\begin{array}{l}\text { Registered } \\
\text { residence }\end{array}$ & permanent & $\begin{array}{l}\text { Urban } \\
\text { Rural }\end{array}$ & $\begin{array}{l}\text { No } \\
30.9 \% \\
37.0 \%\end{array}$ & $\begin{array}{l}\text { Yes } \\
69.1 \% \\
63.0 \%\end{array}$ \\
\hline
\end{tabular}

Sources: developed by the authors.

Besides Table 8 shows that 69.1 percent of urban household registration respondents are willing to participate in the long-term care insurance system. In comparison, 63 percent of rural household registration respondents are willing to participate in the long-term care insurance system. It suggests that people with urban residence have a slightly greater need for long-term care insurance than rural residents.

Age.

Table 9. Cross-table between age and willingness to take long-term care insurance

\begin{tabular}{llll}
\hline Variable & Statistical indicators & Are you willing to sign up for long-term care insurance \\
\hline \multirow{3}{*}{ Age } & & No & Yes \\
& $18-30$ & $35.2 \%$ & $64.8 \%$ \\
& $31-40$ & $27.3 \%$ & $72.7 \%$ \\
& $41-50$ & $28.6 \%$ & $71.4 \%$ \\
& $51-60$ & $11.1 \%$ & $88.9 \%$ \\
\hline
\end{tabular}

Sources: developed by the authors. 
Table 9 shows that $64.8 \%$ of people aged 18 to 30 are willing to take out long-term care insurance. Among the «30-40» age group, $72.7 \%$ of respondents were willing to take out long-term care insurance; $71.4 \%$ of «41-50» age groups are willing to sign up for long-term care insurance; $88.9 \%$ of people in the «51-60» age group are willing to take out long-term care insurance; 40 percent of those «61 and above» are willing to sign up for long-term care insurance. The statistical results showed that the age with a strong desire to participate is mainly concentrated in the «31-60 years old». People aged between 18 and 30 are younger and healthier, and they may not think about the long term. However, the younger generation has a stronger sense of insurance development, so the demand intention between 18 and 30 is not as strong as that between 31 and 60 , but it is also quite strong. However, the demand willingness of «61 and above» is particularly low, which may be related to the conservative thinking of this group of people and the short term of enjoyment, and also partly due to the small number of data and deviation of data.

Whether the elderly have lost their abilities or lost their wits? This question was also raised during this investigation.

Table 10. Crosstable of disability or dementia in the family and willingness to participate in longterm care insurance

\begin{tabular}{lllc}
\hline Variable & Statistical indicators & Are you willing to sign up for long-term care insurance \\
\hline \multirow{3}{*}{ Disable or silly older } & & No & Yes \\
& No & $35.1 \%$ & $64.9 \%$ \\
& Yes & $27.3 \%$ & $72.7 \%$ \\
\hline
\end{tabular}

Sources: developed by the authors.

Table 10 demonstrates that $64.9 \%$ of the elderly without disability or dementia are willing to participate in the long-term care insurance system. The percentage of disabled or mentally disabled seniors in the family willing to participate in long-term care insurance is $72.7 \%$. From this, the willingness to participate in long-term care insurance is relatively high on the whole, and families with disabled or mentally disabled elderly people have a greater demand for a long-term care insurance system than families with no disabled or mentally disabled elderly people.

Income.

Table 11. Crosstable between income and willingness to participate in long term care insurance

\begin{tabular}{|c|c|c|c|}
\hline \multirow[t]{2}{*}{ Variable } & \multirow[t]{2}{*}{ Statistical indicators } & \multicolumn{2}{|c|}{$\begin{array}{l}\text { Are you willing to sign up for long-term care } \\
\text { insurance }\end{array}$} \\
\hline & & No & Yes \\
\hline \multirow[t]{5}{*}{ Income } & Less than 2000yuan & $34.6 \%$ & $65.4 \%$ \\
\hline & 2000-4000yuan & $31.0 \%$ & $69.0 \%$ \\
\hline & 4000-6000yuan & $25.9 \%$ & $74.1 \%$ \\
\hline & $6000-8000 y u a n$ & $33.3 \%$ & $66.7 \%$ \\
\hline & Above 8000 yuan & $63.6 \%$ & $36.4 \%$ \\
\hline
\end{tabular}

Sources: developed by the authors.

As could be seen from Table 11, the proportion of those willing to participate in the long-term care insurance system with an income of «less than 2,000 yuan» is $65.4 \%$; the proportion of those willing to participate in the long-term care insurance system with an income of «2000-4000 yuan» is 69\%; the proportion of those willing to participate in the long-term care insurance system with an income of «40006000 yuan» is $74.1 \%$. The proportion of those with income of «6000-8000» willing to participate in the long-term care insurance system was 66.7 percent. The proportion of those with income of «over 8000 yuan» willing to participate in the long-term care insurance system was $36.4 \%$. It could be seen that income 
H., Yin, Zh., Huo, N., Klietsova, Z., Li, Y., Zhang. Innovations in Human Resource Management: Willingness and Ability of Long-Term Care Insurance

in the «0-6000 yuan» on the long-term care insurance system increases demand. The demand for a longterm care insurance system with more than 6,000 yuan income shows a decreasing trend. This may be because this part of higher-income groups would consider commercial insurance more or because there are small data and biased results.

Regression analysis is a statistical method to determine whether and to what extent dependent and independent variables are significant (Yuan, 2017). Since demand willingness is a dichotomous variable (divided into willing and unwilling), this paper would use the binary Logistic model for regression analysis. The formula of the model: Logit( $P)=\beta_{0}+\beta_{1} X_{1}+\beta_{2} X_{2}+\beta_{3} X_{3}+\cdots \beta_{i} X_{i}$. Among them, the probability of $P$ for residents in Henan province to purchase long-term care insurance, $\beta_{0}$ is constant, $\beta_{i}$ said the I variable $X_{i}$ partial regression coefficient.

Selection and assignment of variables. The results could be seen in Table 12.

Table 12. Selection and assignment of variables

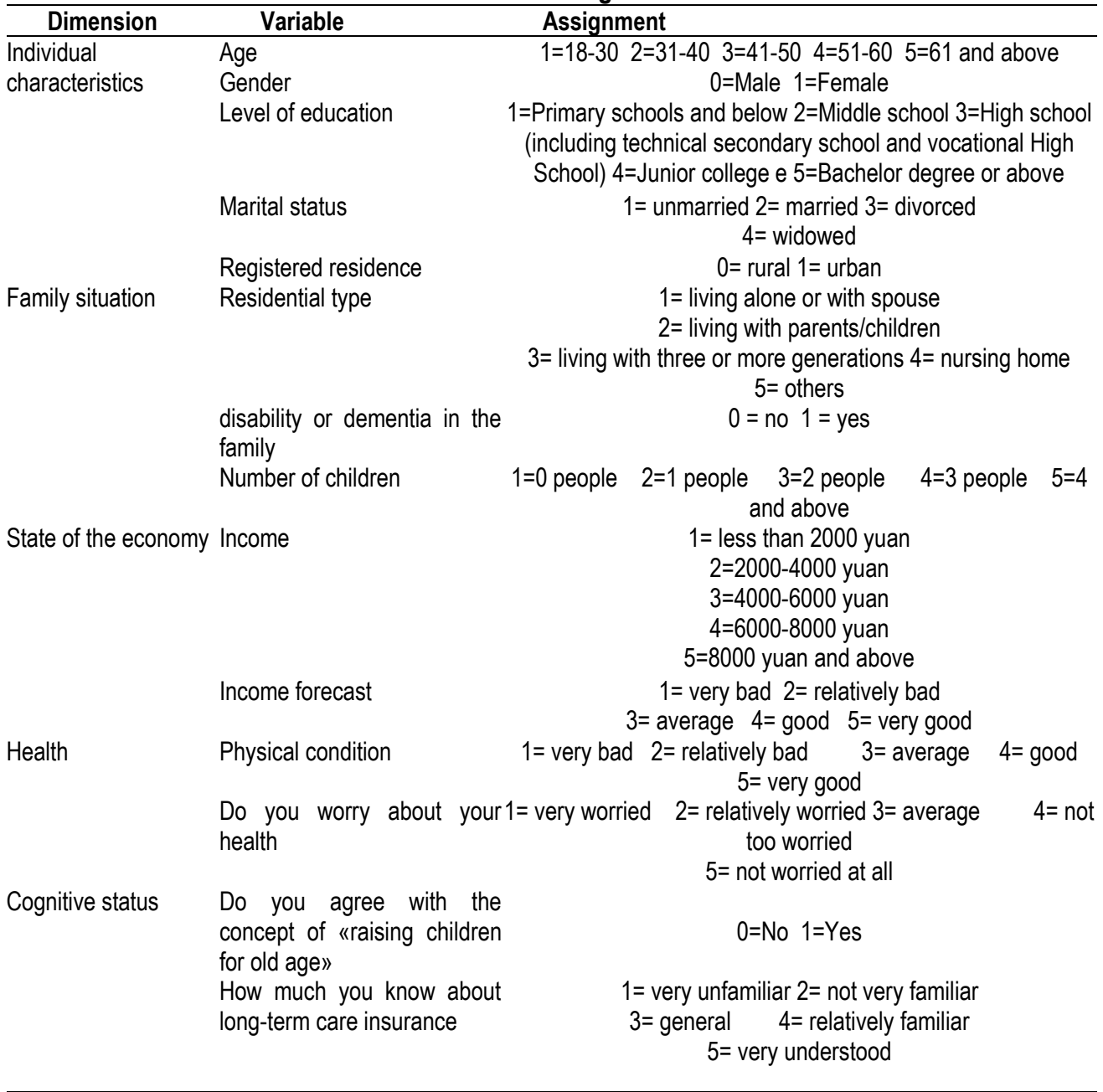


H., Yin, Zh., Huo, N., Klietsova, Z., Li, Y., Zhang. Innovations in Human Resource Management: Willingness and Ability of Long-Term Care Insurance

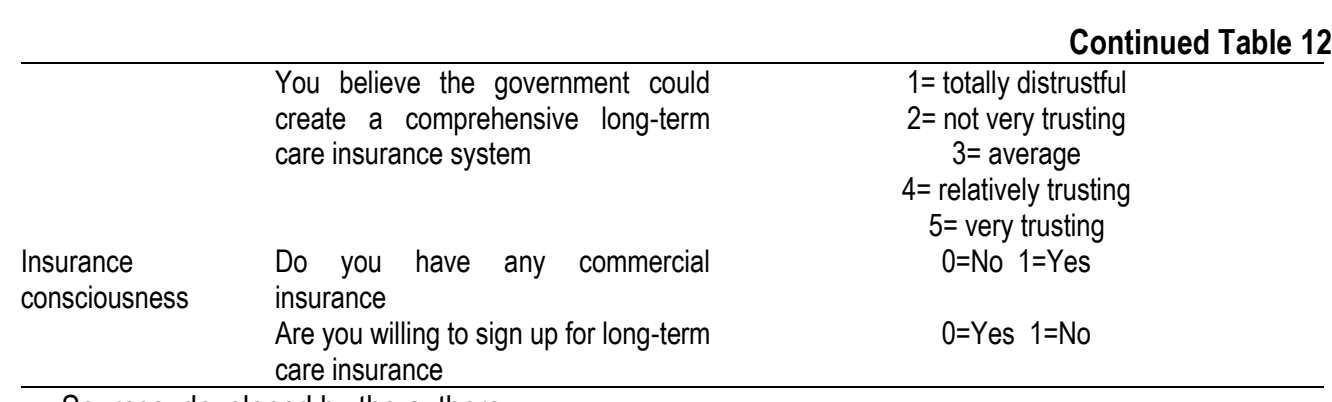

Sources: developed by the authors.

Data analysis.

Table 13. Model fitting information

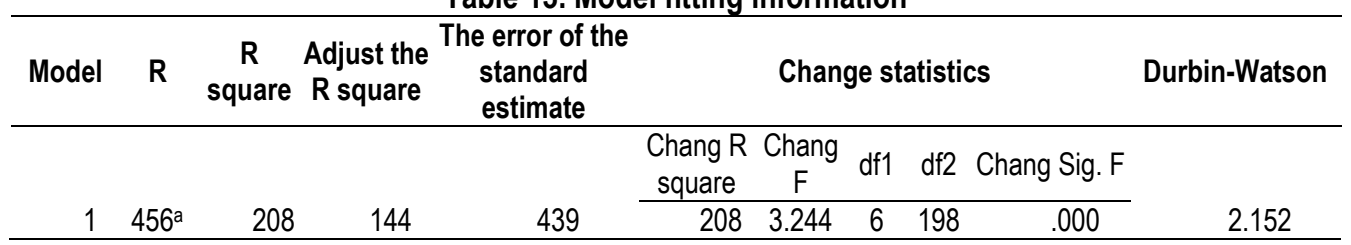

Sources: developed by the authors.

It could be seen from the table that $R=0.456(>0.4)$, and the model has a good fitting degree. DurbinWatson's test value is 2.152 (Durbin-Watson's value is around 2), indicating that the model has no autocorrelation and is well constructed.

Table 14. Regression model for voluntary participation in long-term care insurance

\begin{tabular}{|c|c|c|c|c|c|c|c|}
\hline \multirow[t]{2}{*}{ Model } & \multicolumn{2}{|c|}{$\begin{array}{c}\text { Nonstandardized } \\
\text { coefficient }\end{array}$} & \multirow{2}{*}{$\begin{array}{c}\begin{array}{c}\text { Standard } \\
\text { coefficient }\end{array} \\
\text { A trial version }\end{array}$} & \multirow[t]{2}{*}{$\mathrm{t}$} & \multirow[t]{2}{*}{ Sig. } & \multicolumn{2}{|c|}{ Collinear statistics } \\
\hline & $B$ & Standard error & & & & Allowance & VIF \\
\hline 1. (Constant) & 1.515 & .367 & & 4.134 & .000 & & \\
\hline 2.Registered residence & .003 & .066 & .003 & .041 & .968 & 821 & 1.217 \\
\hline 3.Gender & -.059 & .069 & -.059 & -.849 & .397 & .820 & 1.219 \\
\hline 4. Age & -.104 & .064 & -.194 & 1.632 & .104 & .283 & 3.538 \\
\hline 5.Education background & -.075 & .049 & -.147 & 1.536 & .126 & .438 & 2.285 \\
\hline 7.Marital status & -.081 & .140 & -.077 & -.579 & .563 & .228 & 4.380 \\
\hline 8.Number of children & .062 & .072 & .117 & .861 & .390 & .217 & 4.617 \\
\hline 9. Residence status & -.115 & .047 & -.165 & -2.451 & .015 & .879 & 1.138 \\
\hline 11.Physical condition & -.017 & .046 & -.027 & -.383 & .702 & .799 & 1.251 \\
\hline $\begin{array}{l}\text { 12.Whether have } \\
\text { disabled or silly older }\end{array}$ & -.043 & .105 & -.027 & -.406 & .685 & .881 & 1.135 \\
\hline $\begin{array}{l}\text { 17. Do you worry about } \\
\text { your health }\end{array}$ & .107 & .033 & .228 & 3.246 & .001 & .815 & 1.227 \\
\hline $\begin{array}{l}\text { 18. Do you agree with } \\
\text { the concept of «raising } \\
\text { children for old age» }\end{array}$ & .004 & .065 & .004 & .060 & .952 & .877 & 1.140 \\
\hline $\begin{array}{l}\text { 20. Do you have any } \\
\text { commercial insurance }\end{array}$ & -.007 & .069 & -.007 & -.097 & .923 & .850 & 1.177 \\
\hline
\end{tabular}


H., Yin, Zh., Huo, N., Klietsova, Z., Li, Y., Zhang. Innovations in Human Resource Management: Willingness and Ability of Long-Term Care Insurance

\begin{tabular}{llllllll}
\hline & & & & & & \multicolumn{3}{c}{ Continued Table 14 } \\
\hline $\begin{array}{l}\text { 21. Do you know long- } \\
\text { term care insurance and }\end{array}$ & -.082 & .038 & -.159 & -2.180 & .030 & .754 & 1.327 \\
related policies before? & & & & & & & \\
22.You believe the & -.159 & .044 & -.251 & -3.585 & .000 & .814 & 1.228 \\
government could create & & & & & & & \\
a comprehensive long- & & & & & & & \\
term care insurance & & & & & & & \\
system & & & & & & & \\
28. Income & .037 & .032 & .090 & 1.182 & .238 & .697 & 1.436 \\
29. Income forecast & -.006 & .040 & -.011 & -.154 & 877 & .757 & 1.321 \\
\hline
\end{tabular}

Sources: developed by the authors.

As shown in Table 14, the collinear diagnostic VIF value of regression analysis was 4.617 at the maximum and 1.135 at the minimum. Both of them were less than 10 . Therefore, there is no collinearity problem in this model, so regression analysis could be carried out. Each factor of the individual characteristics model and the Q24 «Do you want to participate in the long-term care insurance system» regression is not significant, indicating that the individual characteristics factor is not an influential factor in the demand for long-term care insurance. Therefore, the original hypothesis was accepted that there is no significant relationship between individual characteristics model factors and long-term care insurance demand intention. The regression of $\mathrm{Q} 9$ «your current residence type» factor in the family status model and Q24 «are you willing to participate in the long-term care insurance system» is significant, indicating that the $Q 9$ «your current residence type» factor in the family status model is an influential factor in the old-age care insurance demand. Therefore, the original hypothesis was rejected. The $Q 9$ «your current living type» factor in the family status model has a significant relationship with the long-term care insurance demand intention, and the significance level is 0.05 . Each factor of the economic status model and the Q24 «Are you willing to participate in the long-term care insurance system» regression are not significant, indicating that the economic status model factor is not affecting the elderly care insurance demand. Therefore, the original hypothesis was accepted that the factors of the economic status model have no significant relationship with long-term care insurance demand intention. In the health status model, there was a significant regression between Q17, «how concerned you are about being incapacitated or lost in old age» and Q24, «are you willing to participate in the long-term care insurance system», indicating that Q17, «How worried you are about being incapacitated or lost in old age» is a factor influencing the demand for long-term care insurance. Therefore, the original hypothesis was rejected. Q17 «you worry about disability or dementia in your old age» factor has a significant relationship with long-term care insurance demand intention, and the significance level is 0.01 . Cognitive models of Q21 «before this, do you know long-term care insurance», Q22 «your trust in the government's ability to establish a sound long-term care insurance system» and Q24 «are you willing to participate in the long-term care insurance system» return significantly, explain Q22 «for the government to set up perfect long-term care insurance system of trust» is the factors affecting demand for long-term care insurance.

Therefore, the original hypothesis is rejected, and Q21 «have you known about long-term care insurance and related policies before,» and Q22 «How much trust do you have in the government's ability to establish a sound long-term care insurance system» are significantly correlated with the demand willingness of long-term care insurance, with the significance level of 0.05 and 0.01 , respectively.

The factors of the insurance awareness model and the regression of Q24 «are you willing to participate in the long-term care insurance system» are not significant, indicating that the insurance awareness factor is not an influential factor for the old-age care insurance demand. Therefore, the original hypothesis is 
H., Yin, Zh., Huo, N., Klietsova, Z., Li, Y., Zhang. Innovations in Human Resource Management: Willingness and Ability of Long-Term Care Insurance

denied, and the insurance consciousness model factors are not significantly related to the willingness of demand for long-term care insurance.

Results. To deal with the responsible staff, some indicators that could influence their behavior should be understood. And first of all, it's «Ability analysis of long-term care insurance participation».

Basic information of insured capacity: Annual payment.

Table 15. Frequency analysis of annual payment

\begin{tabular}{lll}
\hline Annual payment & Frequency & The percentage $(\%)$ \\
\hline Up to 10 yuan & 37 & 17.1 \\
$10-30$ yuan & 30 & 13.9 \\
$30-50$ yuan & 41 & 19.0 \\
$50-70$ yuan & 22 & 10.2 \\
$70-90$ yuan & 7 & 3.2 \\
$90-110$ yuan & 45 & 20.8 \\
110 yuan and above & 34 & 15.7 \\
Total & 216 & 100.0 \\
\hline
\end{tabular}

Sources: developed by the authors.

It could be seen from the above table that the frequency of annual payment «90-110 yuan» is the highest, followed by «30-50 yuan», accounting for $19 \%$, and the frequency of annual payment «Up to 10 yuan» and «110 yuan and above» is also higher. It could be learned from the different attitudes of different long-term insurance payers. It suggests that a certain degree of flexibility is necessary for designing a long-term care insurance system, and the annual payment could be divided into different levels.

Payment period.

Table 16. Frequency analysis of payment years

\begin{tabular}{lll}
\hline Payment period & Frequency & The percentage (\%) \\
\hline Within 5 years & 101 & 46.8 \\
6-10 years & 77 & 35.6 \\
11-15years & 22 & 10.2 \\
16-20years & 8 & 3.7 \\
More than 20 years & 8 & 3.7 \\
Total & 216 & 100.0 \\
\hline
\end{tabular}

Sources: developed by the authors.

Table 16 shows that most people tend to have a shorter payment period related to the current society. After all, it is a rapidly developing society now, and people are under great pressure from various mortgage and car loans. When other conditions do not change much, people tend to have shorter contributory years.

The second step is an analysis of the influencing factors of insurance ability. Cross contingency table and chi-square test were used to analyze the influencing factors of long-term care insurance ability.

Cross analysis. Crosstable of the number of children and annual contribution.

Table 17. Crosstable of number of children and annual contribution

\begin{tabular}{|c|c|c|c|c|c|c|c|c|}
\hline & Variable & & & & Innual payn & ment & & \\
\hline Variable & $\begin{array}{c}\text { statistical } \\
\text { index }\end{array}$ & $\begin{array}{l}\text { Up to10 } \\
\text { yuan }\end{array}$ & $11-30$ yuan 3 & $1-50$ yuan 5 & $51-70$ yuan 7 & $71-90$ yuan & $91-110$ yuan & $\begin{array}{c}\text { Above } 110 \\
\text { yuan }\end{array}$ \\
\hline $\begin{array}{l}\text { Number of } \\
\text { children }\end{array}$ & $\begin{array}{l}0 \\
1\end{array}$ & $\begin{array}{l}16.0 \% \\
16.7 \%\end{array}$ & $\begin{array}{l}13.0 \% \\
16.7 \%\end{array}$ & $\begin{array}{l}19.5 \% \\
16.7 \%\end{array}$ & $\begin{array}{c}13.0 \% \\
0 \%\end{array}$ & $\begin{array}{c}3.0 \% \\
0 \%\end{array}$ & $\begin{array}{l}18.9 \% \\
27.8 \%\end{array}$ & $16.6 \%$ \\
\hline
\end{tabular}


H., Yin, Zh., Huo, N., Klietsova, Z., Li, Y., Zhang. Innovations in Human Resource Management: Willingness and Ability of Long-Term Care Insurance

Continued Table 17

\begin{tabular}{|c|c|c|c|c|c|c|c|}
\hline 2 & $25.0 \%$ & $10.0 \%$ & $15.0 \%$ & $.0 \%$ & $10.0 \%$ & $35.0 \%$ & $5.0 \%$ \\
\hline 3 & $0.0 \%$ & $40.0 \%$ & $20.0 \%$ & $.0 \%$ & $.0 \%$ & $20.0 \%$ & $20.0 \%$ \\
\hline 4and above & $50.0 \%$ & $25.0 \%$ & $25.0 \%$ & $.0 \%$ & $.0 \%$ & $0 \%$ & $.0 \%$ \\
\hline
\end{tabular}

Sources: developed by the authors.

It could be seen from the above table that the annual payment amount of « $30-50$ yuan» is the most when the number of children is $0 ;$ « $90-110$ yuan» is the most when the number of children is $1 ; « 90-110$ yuan» is the most when the number of children is 1 ; «10-30 yuan» is the most when the number of children is 3; «10-30 yuan» is the most when the number of children is 3 The amount of «less than 10 yuan» is the most. It was defined that with the increase of the number of children, the amount of annual payment decreases to a certain extent.

Crosstable of age and payment years.

Table 18. Crosstable of age and payment period

\begin{tabular}{ccccccc}
\hline \multirow{2}{*}{ Variable } & $\begin{array}{c}\text { Variable statistical } \\
\text { index }\end{array}$ & $\begin{array}{c}\text { Less than } \mathbf{5} \\
\text { years }\end{array}$ & $\mathbf{6 - 1 0}$ years & 11-15 years & 16-20 years & $\begin{array}{c}\text { Above 21 } \\
\text { years }\end{array}$ \\
\hline Age & 18-30 years old & $46.4 \%$ & $35.8 \%$ & $10.1 \%$ & $3.9 \%$ & $3.9 \%$ \\
& $31-40$ years old & $54.5 \%$ & $27.3 \%$ & $9.1 \%$ & $0.0 \%$ & $9.1 \%$ \\
& 41-50 years old & $50.0 \%$ & $28.6 \%$ & $21.4 \%$ & $0.0 \%$ & $0.0 \%$ \\
& & & & & $11.1 \%$ & $0.0 \%$ \\
& 51-60 years old & $33.3 \%$ & $55.6 \%$ & $0.0 \%$ & $0.0 \%$ & $0.0 \%$ \\
\hline
\end{tabular}

Sources: developed by the authors.

Table 18 shows that people of all ages are more inclined to pay for a shorter period. The proportion of people of different ages who choose to pay within five years is $46.4 \%, 54.5 \%, 50 \%, 33.3 \%, 66.7 \%$.

Chi-square test.

Table 19. Chi-square analysis of monthly income * annual payment

\begin{tabular}{llll}
\hline & Rang & $\mathrm{d}_{\mathrm{f}}$ & Progressive Sig. (bilateral) \\
\hline Pearson Chi-square & $37.950^{\mathrm{a}}$ & 28 & .099 \\
likelihood ratio(LR) & 44.757 & 28 & .023 \\
N in effective cases & 216 & & \\
\hline
\end{tabular}

Sources: developed by the authors.

As could be seen from the table above, the $p$-value of chi-square is 0.099 . Because $P$-value is greater than a, the original assumption could be accepted that monthly income and annual fee are independent and unrelated.

Table 20. Chi-square test of the number of children * annual payment

\begin{tabular}{llll}
\hline & Rang & $\mathbf{d}_{\mathrm{f}}$ & Progressive Sig. (bilateral) \\
\hline Pearson Chi-square & $53.516^{\mathrm{a}}$ & 28 & .003 \\
likelihood ratio(LR) & 40.039 & 28 & .066 \\
$\mathrm{~N}$ in effective cases & 216 & & \\
\hline
\end{tabular}

Sources: developed by the authors. 
It could be seen from the above table that the $p$-value of chi-square is 0.003 . Suppose the significance level a is 0.05 , and the P-value is less than a. In that case, the original hypothesis that there is a correlation between the number of children and the annual payment could be rejected.

Table 21. Chi-square test of age * payment years

\begin{tabular}{llll}
\hline & Rang & $\mathbf{d}_{\mathrm{f}}$ & Progressive Sig. (bilateral) \\
\hline Pearson Chi-square & $9.412^{\mathrm{a}}$ & 16 & .895 \\
likelihood ratio(LR) & 11.378 & 16 & .786 \\
$\mathrm{~N}$ in effective cases & 216 & & \\
\hline
\end{tabular}

Sources: developed by the authors.

Table 21 shows the probability P-value of chi-square is 0.895 . If the significance level $A$ is set at 0.05 , then the $\mathrm{P}$-value is greater than $\mathrm{A}$. Therefore, the original hypothesis should be accepted, and it is believed that the age and the years of payment are independent and unrelated. Through investigation and analysis, it was found that more than $65 \%$ of the respondents are willing to participate in long-term care insurance. Generally speaking, the respondents prefer to choose the form of home-based care and professional care. Through the cross contingency table analysis, it was found that the demand willingness of long-term care insurance is affected by the location of household registration, age, whether there are disabled or mentally retarded elderly in house, income, and other factors. For example, people with urban registered permanent residence are more willing to demand long-term care insurance than people with rural registered permanent residence; to a certain extent, the older the age, the greater the demand for long-term care insurance; the disabled or mentally retarded elderly at home are more willing to demand long-term care insurance; within a certain range, the higher people's income, the greater the demand for long-term care insurance The higher people's income, the less they need long-term care insurance. Through regression analysis, it was found that worries about one's own health and trust in the government's ability to establish a sound long-term care insurance system would increase the demand for long-term care insurance to a certain extent. This paper also finds that people tend to have a shorter period and have a greater difference in payment amount, so it should be designed differently and flexibly. The ability to participate in insurance is also affected by income, the number of children, and other factors.

Conclusions. It was defined that the human resource management of willingness and ability of longterm care insurance should be present in any country. Summing up the results of the held scientific research it could be done the following recommendations. First of all, strengthening publicity and standardize management of long-term care insurance system. The survey shows that although some people have changed their views on the traditional concept of child care, many people still agree with the traditional concept of child care and simultaneous interpreting. In addition, the survey results also show that most people did not know about the long-term care insurance system before, but after knowing about the long-term care insurance system, more than $65 \%$ of the respondents are willing to participate in the insurance. It could be seen that people's old-age care is greatly influenced by the traditional concept and lack of understanding of long-term care insurance, but there is a great demand for long-term care insurance. It requires the government to actively play a guiding role, change the idea that some people only rely on their children to solve the pension problem when conditions permit and let people accept longterm care insurance to avoid risks. In addition, the government and insurance companies should actively promote the long-term care insurance system so that people could learn more about the long-term care insurance system. Some respondents hold a distrusting attitude on the two issues of «the government could establish a perfect long-term care insurance system» and «the regulatory department could ensure the long-term care insurance system». Therefore, the government and insurance companies should standardize the management and operation of the long-term care system to trust the system more. 
Secondly should be accelerated the development of the nursing industry. With aging, chronic diseases, and other increasingly serious, China's medical resources are very scarce, especially in the nursing industry. At present, two very important problems of long-term care insurance are "who would provide nursing service» and "what is the specific content of long-term care service». China's nursing service system presents the characteristics of youth and specialization, but the number of people engaged in the nursing industry is too small. The current situation of the medical care industry is that more and more people are needed, but less and less professionals could be provided. At present, many elderly care institutions recruit inexperienced personnel to serve as long-term professional managers. The quality of such care is very poor. In recent years, although the number of nursing institutions in China is increasing, the number of beds for the elderly is still short. Although there are no specific requirements for the content of long-term care services in many areas, it is necessary to standardize the content of long-term care services.

Thirdly, it would be progressive if China absorbed the foreign long-term care insurance experience. The second part of the article shows that foreign countries explored long-term care insurance earlier than China. The management mode and some related systems of foreign long-term care insurance are more mature. Different foreign countries have different systems and practices of long-term care insurance. It could be learned from the foreign long-term care insurance system to formulate a suitable long-term care insurance system and mode in China based on China's national conditions. It could be learned from the lessons of long-term care insurance in Western Europe. The operation of long-term care insurance should not include too much government responsibility. Otherwise, it would bring great financial pressure to the government. Therefore, the government, market, and family should play a role in developing long-term care insurance. For example, China could learn from the experience of Germany to a certain extent, and the government could let all residents participate in the insurance to a certain extent, which is conducive to social fairness and justice. At the same time, both the government and the individual bear part of the payment, which reduces the burden of the government and reduces the burden of the individual.

Fourthly, it should be improved the design of long-term care insurance and increased the types of insurance products. The investigation found great differences in people's choices about «the service form of long-term care insurance you want» and «the payment mode of long-term care insurance you prefer». It could be seen that different people have different requirements for long-term care insurance. It requires us to improve the design of long-term care insurance and increase the types of insurance products in formulating long-term care insurance. This way, it could effectively increase the residents' demand for long-term care insurance products and people's satisfaction with long-term care insurance.

Author Contributions: The authors H. Y., Z. H., N. K, Zh. Li and Y. Zh. are equally contributed to the planning, calculating, supervising, and implementing scientific research, analyzing and writing in the form of manuscript. The final version of the manuscript was read and approved by all authors.

Funding: This research received no external funding.

\section{References}

Antosova, I., Hazuchova, N., \& Stavkova, J. (2019). Market Segmentation in Healthcare. Marketing and Management of Innovations, 3, 151-166. [Google Scholar] [CrossRef]

Brown, J. R., \& Finkelstein, A. (2007). Why is the market for long-term care insurance so small?. Journal of public Economics, 91(10), 1967-1991. [Google Scholar] [CrossRef]

Brown, J. R., Goda, G. S., \& McGarry, K. (2012). Long-term care insurance demand limited by beliefs about needs, concerns about insurers, and care available from family. Health Affairs, 31(6), 1294-1302. [Google Scholar] [CrossRef]

D'Ortona, N. E., \& Melisi, G. (2016). Comparison of the claims reserves methods by analyzing the run-off error. Insurance markets and companies: analyses and actuarial computations, (7, Iss. 1), 11-24. [Google Scholar] 
He, H., \& Li, H. (2014). Management Risks and Countermeasures of the Basic Endowment Insurance System for Urban and Rural Residents. Hunan Provincial Government Performance Evaluation and Management Innovation Research Base. Hunan Public Management Research, 5

Huo, Zh., Yin, H., Mykhailov, A., Yan, X., Markina, I., \& Aranchii, V. (2019). Analysis on the current situation and countermeasures of the development of the elderly human resources in China. Collective monograph «Management of the $21^{\text {st }}$ century: globalization challenges»ю Prague, Czech Republic.

Kasaeva, J. (2019). Developing the methodology of assessing the potential of countries to attract foreign direct investment. Marketing and Management of Innovations, 4, 292-307. [Google Scholar] [CrossRef]

Klietsova, N., \& Mykhailova, L. (2021). International Experience in Staff Management in the Process of Staff Recruitment for Vacant Positions with the Application of Social Networks in the Conditions of Digitalization. Education of Economists and Managers, 59(1), 31-46.

Klietsova, N., \& Zhang, Sh. (2020). Scientific investigation concerning optimizing the violation of the persons' labour rights in conditions of «2019-nCoV»: international current issues. Recht der Osteuropäischen Staaten, 1, 57-61. Retrieved from [Link]

Klymchuk, A. O., \& Mikhailov, A. N. (2018). The motivation and stimulation of personnel in effective enterprise management and innovation activity improving. Marketing and Management of Innovations, (1), 218-234. [CrossRef]

Kurylo, M. P., Klochko, A. M., Volchenko, N. V., Klietsova, N. V., \& Bolotina, A. O. (2021). The use of biometric technologies for bank transaction security management against the background of the international experience: Evidence from Ukraine. Banks and Bank Systems, 16, 2, 47-58. [Google Scholar] [CrossRef]

Kuznichenko, P., Frolov, S., Orlov, V., \& Boiko, O. (2021). European Deposit Insurance Scheme implementation: pros and cons. Insurance Markets and Companies, 16(1), 116-126. [Google Scholar]

$\mathrm{Li}, \mathrm{D} .$, \& Wang, M. (2010). The concept of establishing long-term care security system in China. Journal of Insurance Vocational College, 24 (01), 19-22.

Lin, H., \& Prince, J. T. (2016). Determinants of Private Long-Term Care Insurance Purchase in Response to the Partnership Program. Health services research, 51(2), 687-703. [Google Scholar] [CrossRef]

Melnyk, M., Zhabynets, O., Myshchyshyn, I., \& Orlov, V. (2021). Efficient use of the insurance sector potential adjusted for its shadowing: Case of Ukraine. Insurance Markets and Companies, 12(1), 16-31. [Google Scholar]

Mykhailova, L., Stoyanets, N., Mykhailov, A., Kharchenko, T., \& Bachev, H. (2018). Sustainable development of the Ukrainian agrarian sector: perspectives and challenges. Problems and Perspectives in Management, 16(3), 28-39. [Google Scholar] [CrossRef

Sheng, Zh., He, B., \& Zhu, L. (2020). Analysis on the pilot of long-term care insurance system in Suzhou. China Medical Insurance, 2, 37-40.

Shi, B. (2008). Integration Construction of Economic Support and Service Guarantee in Endowment Insurance SystemJapan's «Medium-care Insurance» System and Its Enlightenment. Journal of China Youth University for Political Sciences, 3, 115121.

Szczepanski, M. (2018). The application of behavioral economics to reforming pension systems-edivence from Great Britain and New Zealand. Marketing and Management of Innovations, 3, 201-209. [Google Scholar] [CrossRef]

Szostek, D. (2021). Innovations in Human Resource Management: Impact of Demographic Characteristics, Quality of Interpersonal Relationships on Counterproductive Work Behaviours. Marketing and Management of Innovations, 1, 11-20. [Google Scholar] [CrossRef]

Volosovych, S., Zelenitsa, I., Kondratenko, D., Szymla, W., \& Mamchur, R. (2021). Transformation of insurance technologies in the context of a pandemic. Insurance Markets and Companies, 12(1), 1-13. [Google Scholar]

Xiangyou, W., \& Xueping, L. (2006). Discussion on the development of commercial nursing.

Yang, Sh., Zhao, Y., \& Lin, J. (2017). A little thinking about the definition standard of the elderly population in China. Northwest Population, 38(02), 7-83.

Yanyshyn, Y., Bryk, H., \& Kashuba, Y. (2019). Problems and Perspectives of Internet-Insurance in Ukraine. Marketing and Management of Innovations, 4, 31-38. [Google Scholar] [CrossRef]

Yashkina, O. (2016). Identifying of risks in pricing using a regression model of demand on price dependence. Marketing and Management of Innovations, 3, 76-86. Retrieved from [Link]

Yin, H., Huo, Zh., \& Yan, X. (2019). Theoretical review of long-term care insurance. Modern engineering and innovative technologies, 8, 11-18. Retrieved from [Link]

Yuan, Q. (2017). Study on the Influencing Factors of Elderly Care Insurance Demand in Shanghai. East China University of Political Science and Law Research, 1.

Zaks, A. (2013). Premiums are not necessarily monotonic with interest and age. Insurance Markets and Companies, 4 (2), 13-

19. [Google Scholar] [CrossRef]

Zhang, L. (2011). Feasibility Study of Elderly Care Insurance in China. Shanghai Economic Research, 10, 114-122.

Zhang, X. (2009). Research on long-term care security model. Northern Economy, 2, 16-17.

Хайян Інь, Інститут науки і техніки Хенань, Китай

Чжипінг Хуо, Інститут науки і техніки Хенань, Китай 
H., Yin, Zh., Huo, N., Klietsova, Z., Li, Y., Zhang. Innovations in Human Resource Management: Willingness and Ability of Long-Term Care Insurance

Наталія Клєцова, к.е.н., Сумський національний аграрний університет, Україна

Цункень Лі, Університет Хечжоу, Китай

Йоншен Чжан, Інститут науки і техніки Хенань, Китай

Інновації в управлінні людськими ресурсами: готовність та можливість здійснювати страхування на довготривалий період

Ця стаття присвячена аналізу системи управління людськими ресурсами щодо просування довготривалого страхування у провінції Хенань (Китай) на прикладі міжнародного інноваційного досвіду. Систематизація наукових напрацювань 3 означеної проблематики засвідчила, що науковці переважно застосовують метод опитування для визначення мотивів працівників страхуватись на довготривалий період. Таким чином, у рамках дослідження застосовано метод експертної оцінки для формування опитувальника. Теоретичною та методологічною основою дослідження стали загальні та спеціальні методи наукового пізнання економічних явищ та процесів. У ході дослідження застосовано діалектичний метод для синтезу теоретичних та методологічних основ управління людськими ресурсами щодо готовності та спроможності здійснювати страхування на довгостроковий період. Опитування проводилось із 20 січня по 31 березня 2020 року. За результатами емпіричного дослідження, встановлено, що частка працівників, які мають наміри страхуватись на довготривалий період та рівнем доходу менше ніж 2000 юань становить 65.4\%, із рівнем доходу від 2000 до 4000 юань - 69\%, та з рівнем доходу від 4000 до 6000 юань - 74.1\%. У роботі застосовано регресійний аналіз для визначення статистичної значущості між залежними та незалежними змінними. Дослідження емпірично підтверджує та теоретично доводить, що рівень проінформованості про страхування не впливає на попит на страхові послуги. Результати дослідження мають практичну цінність та можуть бути корисними менеджерам з управління персоналом при формуванні тактики впливу на поведінку працівників. Таким чином, на основі отриманих результатів дослідження автори сформували низку рекомендацій, зокрема: 1) підвищити публічність та стандартизувати систему управління довготривалим страхуванням; 2) сприяти розвитку сестринської справи в Китаї; 3) впроваджувати кращі іноземні практики у сфері довгострокового страхування; 4) удосконалити систему страхування та диверсифікувати страхові послуги.

Ключові слова: страхування, Китай, експертна оцінка, управління людськими ресурсами, інновації, міжнародний досвід, страхування на довготривалий період. 